\author{
DARIUSZ KUPISZ \\ Instytut Historii \\ Uniwersytetu Marii Curie-Skłodowskiej \\ Lublin
}

\title{
PRÓBY ORGANIZACJI WOJSK „OBRONY DOMOWEJ” PRZEZ SZLACHTĘ WOJEWÓDZTW KIJOWSKIEGO, BRACŁAWSKIEGO I CZERNIHOWSKIEGO (1649-1650)
}

\begin{abstract}
Abstrakt: Przedmiotem analizy są próby organizacji wojsk samoobrony terytorialnej przez sejmiki województw kijowskiego, bracławskiego i czernihowskiego w latach 1649-1650. Szlachta województw ukrainnych, ogarniętych powstaniem kozackim, schroniła się wówczas na terenie Wołynia, Rusi i Lubelszczyzny. Miała jednak nadzieję, że po zawieszeniu broni z Bohdanem Chmielnickim zdoła powrócić na Ukrainę, a dzięki własnym, samorządowym siłom zbrojnym przywróci na niej ład i pokój.
\end{abstract}

Słowa kluczowe: powstanie Chmielnickiego, Ukraina, wojsko, samorząd szlachecki.
Abstract: The subject of the analysis are attempts to organize territorial self-defence force undertaken by the dietines of Kiev, Bracłav, and Chernihów palatinates in 16491650. The nobility of the Ukrainian palatinates engulfed by the Cossack uprising, took shelter in the territory of Volhynia, Ruthenia, and the Lublin region. They hoped, however, that after a ceasefire with Khmelnytsky they would return to Ukraine, and thanks to their own self-defence armed forces they would be able to restore order and peace.

Keyw ord s: Khmelnytsky's Uprising, Ukraine, armed forces, noble self-government.

Wybuch powstania Bohdana Chmielnickiego oraz bezkrólewie po śmierci Władysława IV Wazy skłoniły szlachtę wielu ziem i województw Rzeczypospolitej do organizacji oddziałów zbrojnych, tzw. wojska powiatowego. Część z nich tworzono w celu wsparcia armii koronnej, rozbitej już w pierwszej fazie powstania, inne miały zapewnić bezpieczeństwo wewnętrzne na powierzonym im terytorium. W literaturze opisywano już organizację samoobrony przez niektóre sejmiki zachodniej Małopolski, województwa ruskiego, wołyńskiego, a w pewnej mierze także 
Wielkopolski ${ }^{1}$. Nie zajmowano się natomiast szerzej inicjatywami, jakie w tym zakresie podejmowała szlachta województw kijowskiego, czernihowskiego i bracławskiego, czyli terytorium Ukrainy, znajdującego się w samym „epicentrum” buntu. Niniejszy artykuł jest próbą wypełnienia tej luki poprzez ukazanie zarówno planów organizacji wojsk „obrony domowej" przez sejmiki wspomnianych województw ukrainnych, jak też zakresu ich realizacji i możliwości wypełnienia nałożonych na nie zadań. Przyjęte w tytule ramy chronologiczne związane są z okresem działalności tamtejszych oddziałów obrony domowej, które można też określić mianem wojsk samoobrony terytorialnej.

Podstawowym zasobem źródłowym, ukazującym koncepcje tworzenia i proces formowania wojsk obrony domowej, są zawsze materiały związane $\mathrm{z}$ działalnością sejmików. $\mathrm{W}$ tym przypadku były to uchwały (lauda) sejmików województw kijowskiego, bracławskiego i czernihowskiego z lat 1649-1650, powołujące określone jednostki wojskowe, wyznaczające im dowódców, żołd oraz zakreślające cel i ramy działań militarnych ${ }^{2}$. W literaturze zwracano już uwagę, że lauda nie są wystarczającym materiałem do naświetlenia problematyki obrony domowej, bowiem nie wszystkie uchwały sejmików były wprowadzane w życie ${ }^{3}$. Należy analizować również inne ślady działalności samorządu szlacheckiego, a więc uniwersały, manifestacje lokalnych urzędników, powołanych przez samorząd rotmistrzów, pokwitowania wystawiane przez nich dla poborców podatków itp. Nierzadko w sposób znaczący uzupełniają je protestacje sądowe wnoszone do grodów, związane z działalnością funkcjonariuszy

${ }^{1}$ D. Kupisz, Wojska powiatowe samorządów Małopolski i Rusi Czerwonej w latach 1572-1717, Lublin 2008, s. 329-333; idem, Wojsko powiatowe województwa wołyńskiego w XVII wieku, „Науковий вісник Волинського національного університету імені Лесі Українки” 22, 2009, s. 182-188; idem, Ochrona pogranicza przez siły zbrojne samorządu województwa ruskiego $w$ drugiej połowie XVII wieku, w: Urzędy państwowe, organy samorządowe i kościelne oraz ich kancelarie na polsko-ruskim pograniczu kulturowym i etnicznym w okresie od XV do XIX wieku, red. H. Gmiterek, J. Łosowski, Kraków 2010, s. 148-159; idem, Choragwie powiatowe województw małopolskich jako formacje samoobrony terytorialnej w pierwszej połowie XVII wie$k u$, „Studia i Materiały do Historii Wojskowości” 42, 2006, s. 33-57; idem, Choragwie powiatowe ziemi chełmskiej w XVI-XVII wieku, „Rocznik Chełmski” 10, 2006, s. 57-71; J. Dworzaczkowa, Sprawy wojska na sejmikach wielkopolskich w latach 1648-1661, w: Pax et bellum, red. K. Olejnik, Poznań 1993, s. 55-64. Wzmianki o organizowaniu samoobrony terytorialnej w tym okresie znajdują się również w wielu monografiach sejmików ziemskich.

2 Przed ponad stu pięćdziesięciu laty w wydawnictwie Архив Юго-западной России, издаваемый временной комиссией для разбора древних актов (dalej: AJZR), wydano drukiem jedynie część laudów oraz instrukcji poselskich trzech województw ukrainnych oraz województwa wołyńskiego. Interesujące nas materiały zawiera cz. 2, t. 1, Киев 1861, tegoż wydawnictwa.

${ }^{3}$ D. Kupisz, Wojska powiatowe, s. 17-18. 
sejmików czy też powołanych przez nie oddziałów wojskowych. Pozyskanie wymienionych wyżej materiałów stało się możliwe dzięki kwerendzie w zachowanych do naszych czasów księgach grodzkich województw kijowskiego i wołyńskiego, przechowywanych w Centralnym Archiwum Historycznym Ukrainy w Kijowie. Pomocne okazały się również księgi grodzkie województwa lubelskiego, znajdujące się w zasobach Archiwum Państwowego w Lublinie. To przede wszystkim na terenie Wołynia zbierała się na sejmiki wypędzona w 1648 r. ze swych domów szlachta trzech województw ukrainnych, ale z racji sesji trybunalskich spotykała się także w Lublinie. Co prawda luki istniejące w materiale źródłowym, związane z działalnością samorządu szlacheckiego województw ukrainnych, są znaczne (dotyczą w szczególności sejmiku bracławskiego) ${ }^{4}$, lecz kwerenda we wspomnianych księgach grodzkich przyniosła wiele informacji na interesujący nas temat. Uzupełnione korespondencją i innymi źródłami (np. komputami wojsk koronnych), pozwalają one na wyjaśnienie kilku zagadnień związanych z próbami organizacji samoobrony terytorialnej przez sejmiki województw kijowskiego i czernihowskiego, a w pewnej mierze także bracławskiego.

Po wybuchu powstania kozackiego w 1648 r. szlachta kijowska i bracławska poszła w ślady innych województw Rzeczypospolitej i zaciągnęła kilka jednostek wojska powiatowego przeznaczonych do wsparcia armii koronnej. Wiadomo, że Kijowianie zebrali się na sejmiku w Żytomierzu stosunkowo późno, bo dopiero 25 czerwca, w terminie wyznaczonym przez interreksa Macieja Łubieńskiego. Dla porównania warto wspomnieć, że w kilku innych województwach, położonych znacznie dalej od Zaporoża, podjęto uchwały dotyczące obrony i zaciągów już w pierwszych dniach czerwca (np. krakowskie i sandomierskie) $)^{5}$. W Żytomierzu postanowiono przyjąć na żołd 400 kozaków, których oddano pod komendę wojewody kijowskiego Janusza Tyszkiewicza, wybranego wówczas na pułkownika. Rotmistrzami poszczególnych chorągwi zostali: podstoli kijowski Michał Aksak, łowczy nowogrodzki Stefan Lew, podsędek bracławski Krzysztof Tyszkiewicz i Jerzy Hołub ${ }^{6}$. Do pułku wojewódzkiego dołączono też chorągwie prywatne Janusza Tyszkiewicza ${ }^{7}$. Nie jest znana natomiast uchwała

${ }^{4}$ O problemach z tym związanych pisał ostatnio Jarosław Stolicki, Sejmiki ukrainne w latach 1648-1702. Problemy badawcze, w: Patrimonium. Cтудіï з ранньомодерної історії Центрально-Східної Європи, t. 1, Ранньомодерна людина. Простір - влада - право XVIXVIII cm, red. В. Михайловський, Я.Століцький, Краків 2015, s. 225-240.

${ }^{5}$ D. Kupisz, Wojska powiatowe, s. 245-246.

${ }^{6}$ BC, rkp. 417, Laudum województwa kijowskiego, Żytomierz, 25 VI 1648, k. 53v-54.

7 Pamiętniki Samuela i Bogusława Kazimierza Maskiewiczów (wiek XVII), oprac. A. Sajkowski, Wrocław 1961, s. 251. 
sejmiku województwa bracławskiego z czerwca 1648 r. Jan Wimmer podawał, że tamtejsza szlachta zamierzała wystawić 100 husarzy i 500 kozaków, a pułkownikiem owego zaciągu został Samuel Kalinowski ${ }^{8}$. Nic nie wiadomo natomiast o ewentualnych oddziałach zbrojnych wystawionych przez szlachtę czernihowską. Z powodu powstania kozackiego nawet nie była ona w stanie zebrać się w Czernihowie i wzięła udział w czerwcowym sejmiku szlachty wołyńskiej w Łucku' ${ }^{9}$. Wobec szybkiego rozprzestrzeniania się rebelii nie było również możliwości organizacji na Ukrainie powiatowych oddziałów zaciężnych na potrzeby obrony domowej ${ }^{10}$.

Jazda województwa kijowskiego, przeznaczona do obrony państwa, wzmocniła niewielki korpus wojewody ruskiego Jeremiego Wiśniowieckiego, walczyła w lipcu 1648 r. pod komendą Tyszkiewicza pod Machnówką, następnie pod Konstantynowem i Lachowcami ${ }^{11}$. Dotarła również do obozu założonego przez Wiśniowieckiego pod Czołhańskim Kamieniem, gdzie we wrześniu 1648 r. miały się również znaleźć jakieś chorągwie powiatowe województwa bracławskiego ${ }^{12}$. Oddziały te wzięły udział już w pierwszym dniu starć pod Piławcami ${ }^{13}$, a po poniesionej tam klęsce niektórzy rotmistrzowie kijowscy oraz bracławscy dotarli z wojewodą Tyszkiewiczem do Lwowa, gdzie zostali zaciągnięci na dalszą służbę przez Wiśniowieckiego. Ich chorągwie zmieniły wówczas status prawny, bowiem tzw. zaciąg „lwowski” i dokonany nieco później zaciąg „zamojski" przeszły na utrzymanie skarbu państwa ${ }^{14}$.

${ }^{8}$ J. Wimmer, Wojsko polskie w drugiej połowie XVII wieku, Warszawa 1965, s. 49.

9 A. Borowiak, Wojsko powiatowe przed kampania piławiecka 1648 roku, w: Studia nad staropolską sztuka wojenna, t. 2, red. Z. Hundert, Oświęcim 2013, s. 151.

10 Wojewoda bracławski Adam Kisiel powątpiewał, czy w ogóle trzem województwom Ukrainy uda się zebrać jakiekolwiek podatki i wojsko, A. Kisiel do J. Ossolińskiego, Łuck, 29 VII 1648, Sprawy i rzeczy ukraińskie. Materyały do dziejów kozaczyzny i hajdamaczyzny, wyd. F. Rawita-Gawroński, Lwów 1914, s. 22.

${ }_{11}$ Pamiętniki Samuela, s. 249; J. Jerlicz, Latopisiec albo kroniczka, wyd. K.W. Wójcicki, t. 1, Warszawa 1853, s. 67; J. Tomkiewicz, Jeremi Wiśniowiecki (1612-1651), Warszawa 1933, s. 230; D. Płowy, Od Konstantynowa do Piławiec. Działania wojenne na ziemiach ukrainnych od czerwca do września 1648 roku, Zabrze-Tarnowskie Góry 2012, s. 61-62. Autor ostatniej z wymienionych prac nie rozróżnia chorągwi powiatowych od prywatnych jednostek Tyszkiewicza, tymczasem według niektórych źródeł w bitwie pod Konstantynowem walczyły wszystkie cztery chorągwie powiatowe województwa kijowskiego, Z Warszawy, 31 VII 1648 r., BO, rkp. 189, s. 113; BC, rkp. 142, s. 538.

12 A. Borowiak, op. cit., s. 150.

13 W.A. Serczyk, Na płonącej Ukrainie. Dzieje Kozaczyzny 1648-1651, Warszawa 1998, s. 140; D. Kupisz, Wojska powiatowe, s. 256-257; D. Płowy, op. cit., s. 174-182.

${ }_{14}$ Biblioteka Uniwersytetu Wrocławskiego (dalej: BUWr.), rkp. akc. 1949/440, „Komput wojska zaciągu lwowskiego 1 octobris 1648 r.”, k. 317; BC, rkp. 398, „Rozporządzenie wojska koronnego przez J. O. Księcia JMci Wiśniowieckiego we Lwowie prima octobris zaciągnionego", s. 74-76. 
Na sejmie elekcyjnym 1648 r. z obowiązku utrzymywania wojsk powiatowych na potrzeby Rzeczypospolitej zwolniono województwa zniszczone lub zajęte przez nieprzyjaciela, tj. wołyńskie, kijowskie, bracławskie, czernihowskie, podolskie i ziemię halicką ${ }^{15}$. Ułatwiło to tamtejszej szlachcie podjęcie wiosną 1649 r. uchwał mających przywrócić porządek i zapewnić bezpieczeństwo na terenach zagrożonych buntami poddanych. Komisja powołana na sejmie koronacyjnym Jana Kazimierza do rokowań z Chmielnickim dawała nadzieję na uspokojenie Kozaków ${ }^{16}$, ale szlachta uznała, że przywrócenie starego ładu we wschodnich województwach Korony będzie wymagało wystawienia przez nie własnych sił zbrojnych. Decyzje o ich organizacji zapadały na sejmikach obradujących po sejmie koronacyjnym w marcu 1649 r. Podejmowały je zarówno samorządy szlacheckie województw ukrainnych, jak i szlachta ziem leżących bardziej na zachodzie, ale zagrożonych działalnością zbrojnych gromad buntujących się poddanych ${ }^{17}$.

W województwie ruskim najliczniejszy pułk, składający się z 900 żołnierzy, w tym ośmiu chorągwi kozackich i jednej roty pieszej, zaciągnął sejmik halicki ${ }^{18}$. Oddziały halickie, na których czele stał Stanisław Potocki, rozpoczęły służbę 1 kwietnia i kontynuowały ją do 31 października, odnosząc wiele sukcesów w starciach z bandami tzw. opryszków. Prowadziły również budzące kontrowersje, szeroko zakrojone działania o charakterze pacyfikacyjnym, niemniej w znacznym stopniu przyczyniły się do przywrócenia spokoju w ziemi halickiej ${ }^{19}$. Gwoli sprawiedliwości należy dodać, że nie działały tu same, bowiem już z początkiem $1649 \mathrm{r}$. Jan Kazimierz skierował do ziemi halickiej kilka chorągwi koronnych, a wkrótce pojawiło się tu także prywatne wojsko starosty kałuskiego Jana „Sobiepana” Zamoyskiego ${ }^{20}$. Pozostałe ziemie województwa ruskiego, niezagrożone $\mathrm{w}$ takim stopniu jak halicka, przeznaczały na obronę

15 S. Ochmann, Sejm koronacyjny Jana Kazimierza w 1649 r., Wrocław 1985, s. 40; J. Wimmer, Wojsko polskie, s. 48-49.

${ }_{16}$ M. Drozdowski, My o nas i o innych. Szlachta Rzeczypospolitej wobec Kozaczyzny zaporoskiej w latach 1648-1659, Białystok 2015, s. 195-197.

${ }_{17}$ D. Kupisz, Wojska powiatowe, s. 329-333.

18 AGZ, t. 24, Uchwała halicka, 15 III 1649, s. 75-77.

19 Podkreślano zazwyczaj nadużycia, których się dopuszczały, por. С. Томашівський, Народні рухи в Галицькій Руси 1648 р., Лвів 1898, s. 107-108; W. Łoziński, Prawem i lewem. Obyczaje na Czerwonej Rusi w pierwszej połowie XVII wieku, t. 1, Kraków 1957, s. 359-360; A. Czołowski, Z dziejów chmielniczyzny na Podkarpaciu, w: Księga pamiątkowa ku czci Władysława Abrahama, t. 2, Lwów 1931, s. 387-395. Natomiast D. Kupisz, Wojska powiatowe, s. 329-332 wskazywał na powstrzymywanie się rotmistrzów powiatowych ziemi halickiej przed zbyt drastycznymi represjami w porównaniu do oddziałów koronnych.

20 A. Czołowski, op. cit., s. 396-398. 
o wiele skromniejsze środki. Sejmik chełmski uchwalił dwa pobory na zaciąg dwóch chorągwi kozackich (200 koni), z których jedna stacjonowała od maja 1649 r. w Chełmie (Samuela Mirz Brzezickiego), a druga w Krasnymstawie (Ludwika Bądzyńskiego) ${ }^{21}$. Szlachta sanocka wzięła po sejmie koronacyjnym na swój żołd 50 kozaków starosty Franciszka Mniszcha, polecając mu, aby zaciągnął do nich 50 piechoty (oddziały te służyły od marca do października 1649 r. $)^{22}$. W ziemi przemyskiej na zaciąg oddziału obrony domowej zdecydowano się dopiero po wydaniu trzecich wici przez Jana Kazimierza (100 kozaków Gabriela Bireckiego) ${ }^{23}$. Szlachta bełska postąpiła podobnie, bowiem sformowała pułk 300 jazdy kozackiej do obrony domowej dopiero w końcu czerwca lub w lipcu $1649 \mathrm{r}^{24}$, ale ostatecznie zabrała go ze sobą na wyprawę pod Zborów (podobnie postąpili Chełmianie). Na terenach pośrednio zagrożonych buntami, tj. w ziemi lwowskiej i województwie lubelskim, zrezygnowano z podobnych środków ochronnych.

Uczestnicy sejmiku wołyńskiego z 15 marca 1649 r. zamierzali początkowo przystąpić do zorganizowania wyprawy dymowej (wystawienie konnego z 30 dymów), która miała zapewnić im większą liczbę żołnierzy, utrzymywanych mniejszym kosztem. Dwa miesiące później, zapewne z powodu zniszczenia dóbr na skutek działań wojennych, zmienili decyzje i uchwalili poczwórne podymne na zaciąg 1500 kozaków, oddanych pod komendę pułkownika, kasztelana bracławskiego Gabriela Stempkowskiego ${ }^{25}$. Wiadomo, że używano ich w charakterze samoobrony terytorialnej, a latem wysłano $755 \mathrm{z}$ nich pod Zborów ${ }^{26}$.

Szlachta kijowska, bracławska i czernihowska znajdowała się wówczas w o wiele trudniejszym położeniu niż mieszkańcy wspomnianych wyżej województw. Sytuacja polityczno-militarna panująca na Kresach

${ }^{21}$ Laudum ziemi chełmskiej, Chełm, 22 III 1649, w: Akta sejmikowe ziemi chetmskiej 1572-1668, oprac. W. Bondyra, H. Gmiterek, J. Ternes, Lublin 2013, s. 264-265; D. Kupisz, Choragwie powiatowe ziemi chetmskiej, s. 61-62.

${ }_{22}$ AGZ, t. 21, Laudum sejmiku województwa ruskiego, Sądowa Wisznia, 3 III 1649, s. 55; M. Gawęda, Wysiłek zbrojny ziemi przemyskiej i sanockiej w latach 1648-1649, „Rocznik Przemyski" 41, 2005, s. 96.

23 AGZ, t. 21, Laudum ziemi przemyskiej, Przemyśl, 26 VII 1649, s. 56-57; M. Gawęda, op. cit., s 97.

${ }^{24}$ BO, rkp. 15964/II, Laudum województwa bełskiego, Bełz, 11 VI 1649, s. 231. Szerzej o działalności oddziałów samoobrony terytorialnej Rusi Czerwonej w 1649 r. zob. D. Kupisz, Wojska powiatowe, s. 332-333.

${ }^{25}$ Centralnij Deržavnij İstoričnij Archiv Ukraïni, m. Kiïv (dalej: CDIAUK), f. 25, op. 1, sp. 262, Laudum wołyńskie z 15 V 1649, k. 275-277.

${ }^{26}$ BC, rkp. 144, Komput wojska pod Krasnymstawem, 20 VII 1649, s. 717, wzmiankuje jedynie 755 żołnierzy wołyńskich, ale pozostali mogli dołączyć później. D. Kupisz, Wojsko powiatowe województwa wołyńskiego, s. 185. 
w pierwszych miesiącach roku 1649 uniemożliwiała jej powrót do domów i zorganizowanie sejmików w tradycyjnych miejscach. Nie dysponujemy informacjami o posejmowym sejmiku bracławskim, wiadomo natomiast, że grupa szlachty województwa kijowskiego obradowała 15 marca $1649 \mathrm{r}$. w Łucku. W spisanym wówczas laudum zebrani wyrażali nadzieję na rychły powrót do swych majątków. Jednocześnie zdawali sobie sprawę, że nawet po zakończeniu walk z Kozakami przywrócenie ładu i bezpieczeństwa na terenach ogarniętych powstaniem może potrwać kilka lat. W związku z tym uchwalono zaciąg silnego pułku wojewódzkiego, składającego się z 3000 lekkiej jazdy, 1000 dragonii i 300 piechoty niemieckiej, która miała stanowić załogę fortecy horoszkowskiej ${ }^{27}$. Wojsko województwa kijowskiego zamierzano utrzymywać co najmniej dwa lata, ale przewidywano zarówno możliwość przedłużenia żołnierzom służby, jak też zwiększenia lub zmniejszenia liczebności pułku.

$\mathrm{Na}$ dowódcę owej formacji został wybrany podkomorzy kijowski Jerzy Niemirycz, nazwany „pułkownikiem generalnym”. Przyznano mu prawo mianowania rotmistrzów dla poszczególnych chorągwi, a także pułkowników, gdyby zaistniała potrzeba podziału zaciągu. Niemirycz miał w listach przypowiednich, wystawionych dla dowódców, określić rodzaj uzbrojenia wymagany u żołnierzy poszczególnych jednostek. Polecono mu również zadbać, by zgodnie z konstytucjami ostatniego sejmu towarzysze nie zabierali na służbę kosztownych, a zbędnych w wojsku strojów i przedmiotów, nadmiernej liczby wozów, koni i czeladzi. W gestii pułkownika leżało dbanie o dyscyplinę i sądzenie żołnierzy według artykułów wojskowych. Zalecono mu, aby szczególnie ostro karał „tych, którzyby castra deserere, albo z potrzeby uciec mieli, albo się potykać, gdy każą, nie chcieli”28, co wynikało zapewne z doświadczeń kampanii piławieckiej. Wobec przewidywanej dużej liczby spraw kryminalnych „rebellizantów”, pozwolono pułkownikowi ustanowić pełnomocnika, który mógłby go zastępować przed sądem. W wielu kwestiach, w szczególności finansowania wojska i kontrolowania liczebności oddziałów, Niemirycza mieli wspierać wybrani na sejmiku komisarze: stolnik kijowski Władysław Chreptowicz, podstoli kijowski Michał Aksak i Tomasz Kazimierski. Oddziały zamierzano popisywać dwa razy w roku, począwszy od rozpoczęcia służby.

${ }^{27}$ Pod względem liczebności pułk kijowski mógł więc przewyższać wojsko kwarciane według stanu sprzed wybuchu powstania, bowiem to ostatnie liczyło wówczas 4045 stawek żołdu. J. Wimmer, Wojsko i skarb Rzeczypospolitej u schyłku XVI i w pierwszej połowie XVII wieku, „Studia i Materiały do Historii Wojskowości” 14, 1968, 1, s. 91.

${ }^{28}$ AJZR, cz. 2, t. 1, Kiïv 1861, Laudum województwa kijowskiego, Łuck, 15 III 1649, s. 358 . 
Uchylającym się od płacenia podatków na wojsko powiatowe grożono „zajazdem szlachty” całego powiatu w asyście starostów, podobnie zresztą rotmistrzom, którzy wziąwszy pieniądze nie wystawią oddziałów. $\mathrm{Na}$ ich utrzymanie uchwalili Kijowianie potrójne podymne pobierane co kwartał, a w pierwszych trzech miesiącach nawet poczwórne. Łącznie zamierzano zebrać w przeciągu dwóch lat aż 25 podymnych, odrzucono przy tym wszelkie zwolnienia $\mathrm{z}$ owych świadczeń, nakazując stosowanie rejestrów podatkowych sprzed powstania. Sądzono, że pokryje to wszelkie wydatki na wojsko, w tym żołd dla żołnierzy, mający wynieść 581900 zł, przy 30 zł płaconych kwartalnie kawalerzyście i 11 zł dragonowi oraz piechurowi ( $w$ tych ostatnich przypadkach przewidywano też po 11 zł tzw. zaciągowego, nazywanego laffgieldem). Stawka żołdu dla kawalerzystów wskazuje, że zamierzano zaciągać kozaków, a określenie ich mianem lekkiej jazdy odnosiło się zapewne do rezygnacji z uzbrojenia ochronnego. Wynagrodzenie pułkownika, wynoszące $2000 \mathrm{zł}$ kwartalnie, miało być wypłacane z zaległości podatkowych nieuiszczonych przez mieszkańców województwa za lata poprzednie. Z tego samego źródła zamierzano opłacać zakup prochu, kul i innego sprzętu dla fortecy horoszkowskiej, a także wynagrodzenia wywiadowców, rozsyłanych przez pułkownika. Nie określono natomiast pensji dla rotmistrzów oraz ewentualnego źródła ich finansowania.

Żołnierzom obiecano również prowiant, wyliczając, że 20 dymów będzie w stanie wydać go raz na kwartał na jednego żołnierza, „mając wzgląd i na luźną czeladź i konie, bez których żołnierz być nie może"29. Ordynację dotyczącą wymiaru świadczeń w produktach i paszy, wraz z oszacowaniem ich ekwiwalentu pieniężnego, mieli opracować pułkownik i komisarze. Wyrażano nadzieję, że zapobiegnie to nieuzasadnionemu przemieszczaniu się chorągwi po województwie i pobieraniu stacji od miejscowej ludności, co zresztą zostało w laudum zakazane. Wybrano również dwóch posłów, którzy mieli udać się do króla i prosić o wyznaczenie jednego ze starostw na lokum dla komisarzy oraz pułkownika.

Formowanie zasadniczego trzonu wojska miało się odbywać już na terenie województwa kijowskiego w dobrach królewskich i duchownych wszystkich wyznań, według przydziału pułkownika. Oddziały powiatowe zamierzano popisać pod Kijowem lub w innej miejscowości, a następnie rozlokować nad Dnieprem, w jednym lub kilku obozach - zależnie od decyzji dowodzącego. W oparciu o owe obozy pułkownik miał ochraniać całe województwo „od wszelkich tumultów domowych i rebelii”, gromić „swawolne kupy buntowników”, wreszcie chwytać i karać przestępców

${ }^{29}$ Ibidem, s. 359. 
pojawiających się w dobrach królewskich, szlacheckich i duchownych ${ }^{30}$. W przypadku wzrostu zagrożenia Kijowianie deklarowali, że na wezwanie komisarzy lub wojewody (którego aktualnie nie mieli) zwołają pospolite ruszenie i wesprą swych żołnierzy.

Zebrani w Łucku przedstawiciele szlachty kijowskiej zdawali sobie oczywiście sprawę, że wprowadzenie nowych podatków będzie możliwe dopiero po uspokojeniu sytuacji na Ukrainie, nie wyznaczyli więc nawet terminu owego poboru, zlecając to swym komisarzom. Nie chcieli jednak czekać z zaciągami, toteż nakazali pułkownikowi, aby zorganizował choć kilka jednostek jazdy, przyjmując do nich „rozproszonych” po kraju obywateli województwa. Zgodzono się na przyznanie im służby od 1 kwietnia bieżącego roku, a pieniądze na żołd miały pochodzić z dwóch źródeł: reszt z dawnych podatków i pożyczek. Te pierwsze, jak sądzono, pozostawały w ręku kilku poborców, a ich odzyskanie zlecono komisarzom sejmiku. Komisarze uzyskali też wraz z pułkownikiem prawo zaciągania kredytów na określony procent, które miały być spłacane z pierwszego poczwórnego podymnego, uchwalonego na marcowym sejmiku ${ }^{31}$.

Obywatele województwa czernihowskiego zebrali się na sejmiku dopiero 26 kwietnia 1649 r., w kościele Dominikanów w Lublinie, wykorzystując obecność licznych przedstawicieli szlachty na sesji Trybunału Koronnego. Marszałkiem obrad został Jeremi Kazimierz Wojewódzki, podwojewodzi czernihowski i sekretarz królewski. Postanowiono wówczas zaciągnąć ,jako najprędzej 600 człeka konnego, to jest kozaków 400, dragonów cudzoziemców 200 na obronę tak zamków niedoburzonych [w Czernihowie i Nowogrodzie Siewierskim - D.K.], jako ad securitatem domesticam nas wszystkich w województwie". Służba owych chorągwi miała się rozpocząć „od recuperowania za Bożą pomocą [--] województwa i powiatów jego" i trwać dwa lata, bowiem miano nadzieję, że uda się przez ten okres zapanować nad zbuntowaną ludnością ${ }^{32}$. Przewidywano wszakże możliwość przedłużenia żołnierzom powiatowym służby, jak i zwiększenia zaciągu, gdyby pozwalały na to środki finansowe. Były to więc rozwiązania wzorowane na podjętych kilka tygodni wcześniej uchwałach szlachty kijowskiej.

$\mathrm{Na}$ pułkownika zaciągu czernihowskiego wybrano tamtejszego podkomorzego Mikołaja Firleja Broniewskiego, dodając mu trzech komisarzy: chorążego czernihowskiego Gabriela Hulewicza, podsędka

30 Ibidem, s. 357.

31 Ibidem, s. 350-360.

32 Archiwum Państwowe w Lublinie (dalej: APL), Castriensia Lublinensia Relationes (dalej: CLR), sygn. 77, Laudum sejmiku województwa czernihowskiego, Lublin, 26 IV 1649 , k. 223v-224v. 
nowogrodzkiego Piotra Charzewskiego i rotmistrza królewskiego Samuela Załęskiego. Mieli oni przeprowadzić popis chorągwi, nadzorować wypłatę żołdu, wyznaczać z pułkownikiem miejsca zakwaterowania, wymiar stacji i regulować wszelkie inne kwestie aprowizacyjne. Pułkownikowi pozwolono natomiast samodzielnie wybrać rotmistrzów dla poszczególnych chorągwi, zadowalając się zastrzeżeniem dotyczącym powierzania tych funkcji doświadczonym wojskowym. Dużą wagę przywiązywali również Czernihowianie do zaciągania odpowiednich żołnierzy, mając nadzieję, że do dragonii uda się zwerbować cudzoziemców. W każdym razie zabroniono przyjmowania do niej „Rusinów”, nie chciano ich też mieć pośród czeladzi i „pacholików” jazdy kozackiej, bo w obliczu buntu Kozaków zaporoskich „wiary nie dotrzymali”33. Nie było w tym nic dziwnego i obwarowania tego typu odnajdujemy we wszystkich uchwałach sejmikowych województw wschodniej Małopolski, dotyczących zaciągów wojskowych realizowanych po wybuchu powstania Chmielnickiego ${ }^{34}$.

Szlachta czernihowska nie poprzestawała na uchwaleniu zaciągów. Do pułku wojewódzkiego polecono dołączyć żołnierzy łanowych (wybrańców) służących przy zamkach czernihowskim, siewierskim i niżyńskim. Mieli oni wraz ze swymi rotmistrzami podlegać pułkownikowi Broniewskiemu. Obawiając się jednakże, że niewielu z nich przeżyło powstanie, Czernihowianie prosili starostów, aby w porozumieniu z komisarzami sejmiku jak najszybciej nadali opustoszałe łany wybranieckie odpowiednim ludziom. Zobowiązano ponadto starostów, aby w trzech wspomnianych zamkach utrzymywali na swój koszt po 100 piechurów. Szacowano, że dzięki temu siły zbrojne województwa wzrosną do 1200 ludzi: 400 kozaków, 200 dragonów, 300 piechoty starościńskiej i 300 piechoty łanowej. Piechota starostów i łanowi mieli być wykorzystywani przede wszystkim do obrony zamków, a kozacy i dragoni do działań w polu.

Wybrańcy nie zwiększali kosztów utrzymania pułku województwa czernihowskiego, bowiem ich zaopatrzenie w proch oraz kule złożono na barki starostów i dzierżawców (tych pierwszych zobowiązano również, aby odbudowali ze zniszczeń umocnienia Czernihowa i Nowogrodu Siewierskiego). Natomiast koszty utrzymania wojska zaciężnego planowano pokryć z 20 podymnych (po 15 gr od dymu), uchwalonych na dwa lata, obiecując żołd kwartalny w wysokości 30 zł dla kozaka i 11 zł dla dragona, co równało się stawkom kwarcianym. Koszty zakupu chorągwi, bębnów, utrzymania szpiegów, finansowania podjazdów w dalsze rejony

${ }^{33}$ Ibidem.

34 D. Kupisz, Wojska powiatowe, s. 150-153. 
województwa i nagród żołnierskich miały obciążać pułkownika. Obiecano mu jednak aż 2000 zł kuchennego na każdy kwartał, czyli 16000 zł za dwuletni okres służby, a każdy z rotmistrzów miał otrzymywać 300 zł kwartalnego kuchennego.

Podobnie jak Kijowianie, tak i szlachta czernihowska zdawała sobie sprawę, że nie uda się szybko zebrać pieniędzy, stąd jej żołnierze mieli rozpocząć służbę na kredyt. Ściąganie podatków chciano rozpocząć po uspokojeniu sytuacji na Zadnieprzu, w asyście chorągwi powiatowych, które miały ruszyć do województwa czernihowskiego z komisarzami sejmiku. Wówczas to pułkownik, w porozumieniu z komisarzami, powinien rozpisać stanowiska dla oddziałów, informując o tym hetmana koronnego. Miał jednocześnie prosić tego ostatniego, aby nie przyznawał kwater zimowych w województwie dla oddziałów kwarcianych. Pułkownika zobowiązano do osobistego dowodzenia pułkiem, dopuszczając wszakże możliwość wyjazdu w ważnych sprawach (w szczególności na rokowania z Kozakami) i wyznaczenia zastępcy. Przypomniano o przepisach dyscyplinarnych oraz artykułach wojskowych, według których dowódcy mieli sądzić żołnierzy. Każdemu obywatelowi przysługiwało również prawo wnoszenia pozwów przeciw żołnierzom do sądów grodzkich.

Obradująca w Lublinie szlachta czernihowska żywiła nadzieję, że podatki na jej wojsko powiatowe można będzie zbierać już za sześć tygodni, tj. około połowy czerwca, a komisarze, pułkownik i rotmistrzowie będą w stanie przybyć wówczas do Czernihowa. Wybrano nawet poborców oraz opracowano szczegółową procedurę sprawdzania stanu zabudowy wsi i miast. Jednocześnie, wyrazem realizmu był niepokój przed przedłużaniem się buntu kozackiego i deklaracja o możliwości zwołania w Lublinie kolejnego sejmiku ${ }^{35}$.

Obawy szlachty czernihowskiej nie były bezpodstawne, bowiem poselstwu wysłanemu pod przewodnictwem Adama Kisiela do Chmielnickiego udało się 24 lutego 1649 r. wynegocjować jedynie zawieszenie broni. Do czasu rozpoczęcia kolejnej tury rokowań wojska koronne nie mogły wkraczać na tereny województw kijowskiego, bracławskiego i czernihowskiego ${ }^{36}$. Mimo istnienia linii demarkacyjnej, niemal nieustannie dochodziło do starć między wojskiem koronnym a Kozakami oraz do aktów krwawego terroru poddanych skierowanych przeciw szlachcie, która nie

35 APL, CLR, sygn. 77, Laudum sejmiku województwa czernihowskiego, Lublin, 26 IV 1649, k. 225v-229.

36 „Punkta przez jaśniewielmożnego jmci wojewodę bracławskiego i ichmm. panów komisarzów... z Bohdanem Chmielnickim, hetmanem zaporoskim postanowione [--], dnia 24 II 1649 r.", w: Документи Богдана Хмельницъкого 1648-1657, орrac. I. Крип'якевич, Київ 1961, s. 103. 
była w stanie wrócić do swych domów ${ }^{37}$. Nie było żadnej możliwości zebrania podatków we wschodnich województwach Korony, toteż szlachta czernihowska zaniechała na razie realizacji uchwały dotyczącej obrony domowej (nie ma żadnych wzmianek źródłowych dotyczących ewentualnych zaciągów poczynionych w 1649 r. w imieniu tegoż województwa) ${ }^{38}$.

Uchwały dotyczące obrony województw zniszczonych na skutek działań wojennych wywołały zresztą niezadowolenie części szlachty, nieobecnej na obradach sejmików, zwołanych po sejmie koronacyjnym. 7 kwietnia 1649 r. starosta żytomierski Krzysztof Tyszkiewicz, wraz z grupą 28 obywateli województwa kijowskiego, złożył w grodzie lubelskim protestacje przeciw laudum kijowskiemu z 15 marca. Uznawał on, że Jerzy Niemirycz stawił się w Łucku zaledwie z kilkoma przedstawicielami szlachty kijowskiej jedynie w celu obrania deputatów na Trybunał Koronny, tymczasem zapadła tam uchwała obciążająca finansowo województwo zajęte i zniszczone przez nieprzyjaciela ${ }^{39}$. Z podobnymi protestami spotkała się również uchwała województwa wołyńskiego, dotycząca wystawiania wojska łanowego ${ }^{40}$.

Szlachta kijowska doszła jednak do porozumienia, bowiem wzmianki w księgach grodzkich województwa wołyńskiego dowodzą, że zdołała zorganizować na jego terenie kilka jednostek wojska powiatowego. W czerwcu 1649 r. pod bronią znajdowała się chorągiew jazdy pod komendą Aleksandra Chreptowicza, licząca 100 koni. Rotmistrz obiecał żołnierzom po $30 \mathrm{zl}$, powołując się na uchwałę łucką z 15 marca, ale $z$ powodu nieustannych zamieszek na Ukrainie nie otrzymał na ten cel żadnych pieniędzy. Zmuszony był więc zapisać swym podkomendnym 3000 zł za pierwszy kwartał służby na swych dziedzicznych dobrach ${ }^{41}$. O zaciąganiu wojska na mocy laudum kijowskiego świadczą również listy oraz uniwersały królewskie. W początkach lipca Jan Kazimierz pisał do podkomorzego kijowskiego Jerzego Niemirycza, aby na czele swego pułku przesunął się w okolice Zbaraża i starał się prowadzić akcje dywersyjne

37 W.A. Serczyk, op. cit., s. 199.

${ }^{38} \mathrm{Na}$ czernihowskim sejmiku deputackim we wrześniu 1649 r. nie wspominano nawet o organizacji wojska powiatowego, ani też innych formacji zbrojnych. APL, CLR, sygn. 77, Laudum sejmiku województwa czernihowskiego, Lublin, 14 IX 1649, k. 709v.

39 APL, CLR, sygn. 77, Protestacja szlachty województwa kijowskiego zgromadzonej na Trybunale w Lublinie, 7 IV 1649, k. 56-57.

${ }^{40}$ AJZR, cz. 3, t. 4, Kiïv 1914, Protestacja biskupa A. Gembickiego, 22 III 1649, s. 9092; ibidem, Protestacja A.A. Sanguszki, 17 IV 1649, s. 134-137; ibidem, Protestacja A. Kisiela, 21 IV 1649, s. 140.

${ }^{41}$ CDIAUK, f. 25, op. 1, nr 262, Asekuracja A. Chreptowicza, Łuck, 19 VI 1649, k. 411$411 \mathrm{v}$. 
przeciw siłom kozacko-tatarskim oblegającym twierdzę. Koncepcja ta zyskała aprobatę Niemirycza, zakładała bowiem połączenie jego chorągwi z jednostkami, którymi dowodził Samuel Korecki, powiatowym pułkiem wołyńskim dowodzonym przez kasztelana bracławskiego Gabriela Stempkowskiego oraz pułkiem wojewody krakowskiego Władysława Dominika Ostrogskiego-Zasławskiego, pod komendą Krzysztofa Koryckiego ${ }^{42}$. Wszystkim wymienionym tu jednostkom zarzucano jednak, że wobec przewagi nieprzyjaciela i animozji panujących pomiędzy wodzami nie zdołały się połączyć i, błąkając się samodzielnie, nie podjęły poważniejszych działań przeciw wojskom kozackim ${ }^{43}$. Niemniej jednak wiadomo, że przynajmniej jedna z chorągwi województwa kijowskiego (Chreptowicza) walczyła z podjazdami kozackimi, staczając w lipcu 1649 r. potyczkę pod Hnilicami na wschód od Zbaraża ${ }^{44}$.

W tym samym czasie, tj. w pierwszej połowie lipca, Jan Kazimierz zmienił zdanie co do pozostających na Wołyniu jednostek wojskowych i w drodze do Zamościa wystosował uniwersały, nakazując wszystkim chorągwiom ściąganie pod Sokal. W samym Zamościu zaś 23 lipca król wydał uniwersał do szlachty województwa kijowskiego, wzywając ją do swego boku wraz z rotmistrzami "pułku województwa kijowskiego”. Zadeklarował przy tym, że zaciężne oddziały kijowskiego wojska powiatowego, które dołączą do armii maszerującej na odsiecz Zbaraża, zostaną opłacone ze skarbu koronnego „za przeszłą ćwierć i także wkroczoną”45. Była to oferta bardzo atrakcyjna dla żołnierzy województwa opanowanego przez Kozaków, została więc skwapliwie przyjęta.

Wiadomo, że 8 lub 9 sierpnia Niemiryczowie przyprowadzili do obozu królewskiego pod Biały Kamień dwie zaciężne chorągwie kijowskie ${ }^{46}$. $\mathrm{Z}$ całą pewnością jedną z nich dowodził podkomorzy kijowski Jerzy, pełniący jednocześnie funkcję pułkownika, drugą zaś Stefan ${ }^{47}$. Być może

${ }^{42}$ Jan Kazimierz do kasztelana bracławskiego [b.m. b.d] (pierwsza połowa lipca 1649), w: Документы об освободительной войне украинского народа 1648-1654 г2., орrac. А.3. Барабой, И.Л. Бутич, Київ 1965, s. 261.

${ }^{43}$ O owych animozjach i bezczynnym tułaniu się tych wojsk donoszono z obozu królewskiego, ibidem, s. 265.

${ }^{44}$ CDIAUK, f. 25, op. 1, nr 264, „Manifestacja oficerów chorągwi Chreptowicza, w Rastnikach, trzeciego dnia po bitwie pod Hnilicami, mense julii 1649 r.", k. $1119 \mathrm{v}-1120 \mathrm{v}$.

${ }^{45}$ CDIAUK, f. 25, op. 1, nr 262, Uniwersał Jana Kazimierza do szlachty województwa kijowskiego, Zamość, 23 VII 1649, k. 522-523.

${ }^{46}$ Diariusz ekspedycji i transakcji pod Zborowem roku 1649, w: Документы об освободительной войне, s. 243.

${ }^{47}$ CDIAUK, f. 11, op. 1, nr 13, Laudum sejmiku województw kijowskiego i czernihowskiego, Żytomierz, 27 II 1650, k. 83. 
komendę nad całością zaciągu województwa kijowskiego objął wówczas mianowany niedawno tamtejszym wojewodą Adam Kisiel. W jednej z relacji wspominano, że przyprowadził on pod Zborów około 500 ludzi, w tym co najmniej 300 zaciągniętych na mocy uchwały sejmiku województwa kijowskiego ${ }^{48}$. Z kolei „Likwidacja wojska na komisji lubelskiej 1650 r.” dowodzi, że w skład pułku Kisiela wchodziły chorągwie kozackie: Jerzego Niemirycza 100 koni, Remigiana Jelca 79 koni, Stefana Niemirycza 57 koni, Aleksandra Chreptowicza (tu nie podano liczebności, ale jak pisano wyżej liczyła około 100 koni) oraz chorągiew tatarska Wojciecha Kaczyńskiego - 57 koni $^{49}$. Żołd za dwa kwartały roku 1649 wypłaciło tym oddziałom województwo, a pozostałe dwa (drugi i trzeci) opłacił skarb państwa, co było zgodne z deklaracją królewską. Chorągwie te nie weszły wówczas na stałe do komputu ${ }^{50}$, ale, jak świadczy asekuracja dotycząca wypłacania zaległości, wystawiona przez chorążego kijowskiego Jelca jego podkomendnym, płaca ze skarbu ułatwiła utrzymanie żołnierzy w służbie ${ }^{51}$.

Przytoczone tu dane wskazują, że na mocy uchwał sejmiku województwa kijowskiego zaciągnięto na potrzeby obrony domowej pięć chorągwi o łącznej liczebności blisko 400 koni i że wzięły one udział w walkach pod Zborowem. Do wymienionych oddziałów należy doliczyć 100 jazdy kozackiej Kisiela, która również znajdowała się przez dwa kwartały na żołdzie państwowym ${ }^{52}$, ale była to początkowo jednostka prywatna. $\mathrm{Na}$ żołd województwa została przyjęta dopiero od czwartego kwartału 1649 r., stając się tym samym na jakiś czas chorągwią powiatową ${ }^{53}$.

${ }^{48}$ Komput ludzi pod Zborowem (1649), w: Relacje wojenne z pierwszych lat walk polsko-kozackich powstania Bohdana Chmielnickiego okresu „Ogniem i mieczem”. (1648-1651), oprac. M. Nagielski, Warszawa 1999, s. 327; Diariusz ekspedycji i transakcji, w: Документы об освободительной войне, s. 243-244. W innym z komputów wspominano о 2000 „ludzi wołyńskich i kijowskich", Jakuba Michałowskiego wojskiego lubelskiego, a później kasztelana bieckiego księga pamiętnicza, wyd. A.Z. Helcel, Kraków 1864, s. 427.

${ }^{49}$ BUWr., sygn. akc. 1949/440, „Likwidacja wojsk Rzeptej na komisyjej lubelskiej 1650 r.", k. 432v.

$50 \mathrm{~J}$. Wimmer, Materiały do zagadnienia organizacji i liczebności armii koronnej w latach 1648-1655, „Studia i Materiały do Historii Wojskowości” 4, 1958, s. 494 - według zamieszczonego tu wykazu chorągwie J. i S. Niemiryczów oraz Jelca służyły jeszcze od jednego do trzech kwartałów w 1651 r. Wimmer pominął natomiast opłaconą przez dwa kwartały 1649 r. ze skarbu państwa, powiatową choragiew Chreptowicza, por. przyp. 49.

${ }^{51}$ Dowódca powoływał się na laudum uchwalone w Łucku, ale podpisał używając tytułu rotmistrza królewskiego, bo był nim akurat w tym kwartale służby, CDIAUK, f. 25, op. 1, nr 262, Asekuracja Remigiana Jelca, Gurka, 26 VII 1649, k. 523-523v.

${ }^{52} \mathrm{~J}$. Wimmer, Materiały do zagadnienia organizacji, s. 494. Kisiel występuje tu z błędnym imieniem Mikołaj.

${ }^{53}$ AJZR, cz. 2, t. 1, Instrukcja poselska sejmiku województwa kijowskiego, Żytomierz, 15 XII 1651, s. 421-422. 
Niewiele wiadomo o postawie szlachty z dwóch pozostałych województw Ukrainy w dobie kampanii zborowskiej. Dowodzący wówczas armią koronną kasztelan bełski Andrzej Firlej już w maju 1649 r. prosił króla o uniwersały zwołujące pospolite ruszenie województw podolskiego, ruskiego, wołyńskiego i bracławskiego. W zamyśle regimentarza miały one nie dopuszczać do rozszerzania się buntu, ale monarcha zdecydował się wówczas jedynie na wezwanie tych pierwszych pod Kamieniec ${ }^{54}$. W innych źródłach wzmiankowano, że kasztelan bracławski Gabriel Stempkowski, dowodzący chorągwiami sformowanymi przez województwo wołyńskie, przyprowadził oprócz nich do obozu królewskiego 200 ludzi ${ }^{55}$. Po podpisaniu ugody z Kozakami pod Gliniany dotarł jeszcze wojewoda bracławski Władysław Myszkowski ${ }^{56}$. Nie ma jednak informacji, czy którykolwiek z nich przyprowadził ze sobą jednostki wojska powiatowego lub bracławskie pospolite ruszenie.

Ugoda zawarta pod Zborowem pozwalała wprawdzie szlachcie na powrót do jej majątków, jednak wojska zaporoskie obozowały jeszcze przez długi czas na wschodnich krańcach Wołynia i Podola, odcinając de facto terytorium Ukrainy od reszty kraju ${ }^{57}$. Odsuwało to na dalszy czas ambitne plany dotyczące obrony domowej tamtejszych województw, a położonego na Zadnieprzu województwa czernihowskiego w szczególności. Protestacja chorążego koronnego Jelca dowodzi, że egzulanci $z$ tych terenów byli coraz bardziej zniecierpliwieni taką sytuacją ${ }^{58}$. Także król, zwołując na wrzesień sejmiki trzech województw ukrainnych do Włodzimierza podkreślał, że czyni to, bo mimo ugody „tak prędko wojsko

${ }^{54}$ List do NN. senatora, Warszawa, 28 V 1649, w: Документы об освободительной войне, s. 219-220.

55 O zaciężnym wojsku powiatowym województwa wołyńskiego jako gotowym do służby donoszono już w czerwcu 1649 r., CDIAUK, f. 28, op. 1, nr 85, Uniwersał podkomorzego łuckiego H. Czetwertyńskiego, Łuck, 22 VI 1649, k. 401v-402. Z innych źródeł wynika, że pod Zborowem były zarówno niektóre zaciężne chorągwie wołyńskie, jak i przynajmniej część tamtejszego pospolitego ruszenia, ibidem, Atestacja podkomorzego łuckiego H. Czetwertyńskiego dla S. Hawratyńskiego, obóz pod Glinianami, 27 VIII 1649, k. 446v-447; ibidem, f. 25, op. 1, nr 269, Laudum województwa wołyńskiego, Łuck, 12 I 1651, k. 29v-30. O obecności szlachty wołyńskiej pod Zborowem pisał też Mirosław Nagielski, Pospolite ruszenie szlachty w świetle kampanii zborowskiej i beresteckiej przeciw Kozakom (1649-1651), w: Studia Historyczno-Wojskowe, t. 3, Armia i społeczeństwo, red. T. Ciesielski, Zabrze 2009, s. 97. Autor ten pominął jednak chorągwie województwa kijowskiego, nie wspominał również o ewentualnej obecności pospolitaków trzech województw ukrainnych pod Zborowem, uznając 200 ludzi przybyłych z kasztelanem bracławskim Gabrielem Stempkowskim za wolontariuszy lub chorągiew prywatną.

${ }^{56}$ Komput ludzi pod Zborowem (1649), w: Relacje wojenne, s. 329.

57 W.A. Serczyk, op. cit., s. 268.

58 APL, CLR, sygn. 77, Protestacja R. Jelca, Lublin, wrzesień 1649, k. 876v-881v. 
nasze zaporoskie od pospólstwa oddzielone być nie może" i nie widzi możliwości obrad w Żytomierzu, Bracławiu czy Czernihowie ${ }^{59}$.

We wrześniowych uchwałach rozdwojonego sejmiku czernihowskiego nie wspominano już nawet o rozwiązaniu problemu powrotu na Ukrainę i organizacji jej obrony ${ }^{60}$. Obywatele województwa bracławskiego jeszcze w październiku 1649 r. pozostawali na terenie Wołynia i 11 tego miesiąca zebrali się po raz kolejny we Włodzimierzu, tym razem na sejmiku przedsejmowym. Dziękowali tym, którzy stawili się pod Zbarażem i Zborowem, jednak o organizacji własnych sił samoobrony nie wspominali ${ }^{61}$. Bracławianie nie godzili się bowiem na ugodę zborowską, która ich zdaniem doprowadzić mogła do rozbicia integralności Rzeczypospolitej i wybuchu kolejnej wojny. Biorąc to pod uwagę, domagali się wzmocnienia armii państwowej ${ }^{62}$.

Tymczasem wojewoda kijowski Kisiel uzyskał od Chmielnickiego zapewnienie, że będzie mógł spokojnie zorganizować sejmik na terenie swego województwa ${ }^{63}$. Zdołał przekroczyć z grupą szlachty kijowskiej granicę, ale 11 października zmuszony był obradować wraz z nią w szczerym polu nad rzeką Słuczą. Przez cały czas obawiano się postawy Kozaków, toteż zamierzano ruszyć dalej na wschód dopiero po ostatecznym porozumieniu z Chmielnickim i uzyskaniu gwarancji bezpieczeństwa dla szlachty ${ }^{64}$. Wiadomo, że zebranym towarzyszyły dwie chorągwie powiatowe (Adama Kisiela i Jerzego Niemirycza), które po kampanii zborowskiej pozostały w służbie województwa kijowskiego. Zapewne jeszcze w tym samym miesiącu zdołały one dotrzeć do Żytomierza i w oparciu o to miasto próbowały osłaniać przynajmniej zachodnią część Kijowszczyzny. Było to zadanie wręcz niewykonalne. 9 lutego 1650 r. porucznik

${ }^{59}$ CDIAUK, f. 28, op. 1, nr 85, Uniwersał Jana Kazimierza do szlachty województw kijowskiego, bracławskiego i czernihowskiego, Gliniany, 25 VIII 1649, k. 431-445v.

${ }^{60}$ Zapewne z powodu nieporozumienia 13 września 1649 r. doszło do dwóch sejmików deputackich województwa czernihowskiego, część szlachty obradowała w Lublinie, a część we Włodzimierzu, APL, KGL CLR, sygn. 77, Laudum sejmiku województwa czernihowskiego, Lublin, 13 IX 1649, k. 709v; CDIAUK, f. 28, op. 1, nr 85, Laudum sejmiku województwa czernihowskiego, Włodzimierz, 13 IX 1649, k. 448-449v.

${ }^{61}$ CDIAUK, f. 28, op. 1, nr 85, Instrukcja poselska sejmiku województwa bracławskiego, Włodzimierz, 13 X 1649, k. 476-480v.

${ }^{62}$ M. Drozdowski, op. cit., s. 233.

63 B. Chmielnicki do A. Kisiela, Czehryń, 8 X 1649, w: Документи Богдана Хмельницьького, s. 139-140.

${ }^{64}$ A. Kisiel do B. Chmielnickiego, między Zwiahałem a Niesołoną, 12 XI 1649, w: Джерела з історії Національно-визвольної війни українського народу 1648-1658 рp., t. 1: (1648-1649 pp.), oprac. Ю. Мицик, Київ 2012, s. 395-396; A. Kisiel do J. Ossolińskiego, b.m. ok. 16 X 1649, w: Jakuba Michałowskiego, s. 509. 
chorągwi Kisiela donosił z Żytomierza o gromadzeniu się buntowników pod Korosteszowem i zabójstwie kilku szlachciców, którzy wrócili do domów. Z listu wynika ponadto, że podkomendni wojewody wyjeżdżali co drugi dzień na patrolowanie okolic, a ich głównym zadaniem było utrzymanie Żytomierza do zaplanowanych w nim obrad sejmikowych. Wkrótce zostali jednak w tym mieście sami, bowiem Jerzy Niemirycz opuścił go, zabierając przy okazji swoją chorągiew ${ }^{65}$, natomiast sam Kisiel przebywał od listopada 1649 r. w Kijowie ${ }^{66}$.

Nie wiadomo, jakie były przyczyny opuszczenia Żytomierza przez chorągiew Niemirycza, dość, że nie miano o to pretensji do rotmistrza, a ludzie Kisiela zdołali utrzymać miasto. Doceniając zasługi obydwu chorągwi, szlachta kijowska, która 27 lutego 1650 r. zdołała zorganizować sejmik w Żytomierzu, poleciła poborcom opłacić im dwa kwartały służby (czwarty z roku 1649 i pierwszy z 1650 r.) oraz obiecała kolejną ćwierć, liczoną od 1 kwietnia. Z powodu nieustannych buntów i napaści na dwory postanowiono uchwalić dodatkowo jedno podymne na rozbudowę wojska powiatowego o trzy chorągwie jazdy. Na rotmistrzów wybrano starostę nowogrodzkiego Krzysztofa Tyszkiewicza i Stefana Niemirycza, a ponadto pozwolono zaciągnąć drugą chorągiew wojewodzie Kisielowi.

Wspólnie ze szlachtą kijowską obradowali w Żytomierzu obywatele województwa czernihowskiego, którzy uchwalili dwa podymne na zaciągi powiatowe. Planowali utworzenie trzech chorągwi lekkiej jazdy, wybierając na rotmistrzów podkomorzego nowogrodzkiego Jana Piaseczyńskiego, stolnika kijowskiego Włodzimierza Kisiela i stolnika czernihowskiego Romana Zahorowskiego. Żołnierze obydwu województw mieli tworzyć jeden pułk liczący osiem chorągwi (800 jazdy). Komendę nad nim powierzono Adamowi Kisielowi, któremu przyznano 4000 zł kuchennego, a rotmistrzom po $500 \mathrm{zl}$. Nie chcąc zapewne dopuścić do sporów przy okazji wybierania stacji, nie przyznano ich żołnierzom, dodając do $30 \mathrm{zł}$ kwartalnego żołdu po $15 \mathrm{zł} \mathrm{na} \mathrm{prowiant.}$

Na sejmiku wyznaczono również poszczególnym oddziałom miejsca stacjonowania: Radomyśl, Ksawerów, Horoszki, Żytomierz i Czerniehów w województwie kijowskim oraz Nowogródek, Sośnicę i Mglin w czernihowskim. Można odnieść wrażenie, że rozmieszczenie niektórych chorągwi wiązało się z interesami ich dowódców, bowiem Jerzy Niemirycz „pozwolił” swym żołnierzom stacjonować w jego dziedzicznych Horoszkach i Mglinie, a Stefan Niemirycz w Czerniehowie, który należał do

${ }^{65}$ List nieznanego szlachcica, Żytomierz, 9 II 1650, w: Джерела з історії Національно-визвольної війни, t. 2: (1650-1651), Kiїv 2013, s. 13.

${ }^{66}$ A. Kisiel do Jana Kazimierza, Kijów, 28 XI 1649, w: Jakuba Michałowskiego, s. 521. 
niego. Miarą nadziei, jakie wiązała szlachta obydwu województw z organizacją pułku obrony domowej, było zalecenie dane Kisielowi, aby jako pułkownik zaciągów wojewódzkich, a ponadto komisarz Rzeczypospolitej, porozumiał się z Chmielnickim, po czym skierował swych podkomendnych do tłumienia buntów we współpracy z Kozakami $!{ }^{67}$ Podstawą owych koncepcji współdziałania z zaporożcami były z pewnością zapewnienia dotyczące zwalczania wszelkiego rodzaju „swawolników”, jakie wielokrotnie składał Chmielnicki ${ }^{68}$. Natomiast przykładem udanego stłumienia buntów, na którym zapewne zamierzano się wzorować, były działania pułku ziemi halickiej, prowadzone do końca 1649 r. Tyle tylko, że w ziemi halickiej, oddalonej od terenów przyznanych Kozakom, pojawiły się też choragwie koronne i magnackie ${ }^{69}$, a bunt nie przybrał tak wielkich rozmiarów jak na Ukrainie.

Wkrótce okazało się, że zebranie podatków uchwalonych na lutowym sejmiku żytomierskim nie było sprawą łatwą, a obietnice Chmielnickiego są bez pokrycia. Napady na wracającą do domów szlachtę nie ustawały, a Kozacy zakazywali ludności województw kijowskiego, bracławskiego i czernihowskiego wydawania jakichkolwiek pieniędzy poborcom wybranym na sejmikach ${ }^{70}$. Dodatkowym ciosem dla tamtejszej szlachty okazało się stanowisko monarchy, przedstawione jej posłowi 1 maja $1650 \mathrm{r}$. w Warszawie. Pod pretekstem braku jakiejkolwiek wzmianki o planach zaciągania wojska przez sejmiki województw kijowskiego i czernihowskiego na ostatnim sejmie król odmówił zatwierdzenia ich uchwał w zakresie samoobrony i jej finansowania. Zapewniał przy tym, że „sejm obronę tamecznym krajom generalną obmyślił, wojsko także takie sporządziwszy, jakie tych czasów być mogło" "71. Nie ulega wątpliwości, że Jan Kazimierz patrzył bardziej realistycznie na sytuację na Ukrainie niż tamtejsza szlachta. Nie życzył sobie tworzenia na wschodnich rubieżach kraju znacznych pod względem liczebności pułków wojska wojewódzkiego, których działalność mogła dostarczać pretekstu do nowego

${ }^{67}$ CDIAUK, f. 11, op. 1, nr 13, Laudum sejmiku województwa kijowskiego i czernihowskiego, Żytomierz, 27 II 1650, k. 82-84.

68 „Instrukcja [--] na sejm warszawski 1649 r. od wojska j.k.mci zaporoskiego”, w: Документи Богдана Хмельницъього, s. 151; B. Chmielnicki do P. Potockiego, Kijów, 20 III 1650, w: ibidem, s. 156.

${ }^{69}$ D. Kupisz, Wojska powiatowe, s. 330-332.

70 Fragment z listu PP. Rzeczyckiego, Pereworsk, 6 IV 1650, w: Джерела з історії Національно-визвольної війни, t. 2, s. 22; Fragment listu Chodorowskiego - ojca do J. Chodorowskiego, Dmitrów, 9 XII 1650, w: ibidem, s. 44.

71 „Respons urodzonemu Chorathimowi, posłowi od województwa kijowskiego i czernihowskiego od JKM 1 mai 1650", w: Документы об освободительной войне, s. 336. 
konfliktu z Chmielnickim ${ }^{72}$, a utrzymanie przerastało możliwości ziem zniszczonych działaniami wojennymi. Dworowi zależało natomiast na zachowaniu dobrych relacji z Kozakami, których chciano wykorzystać w przypadku konfliktu z Turcją.

Co prawda, nie czekając na odpowiedź monarchy, Kijowianie powiększyli zaciąg, ale była to ich ostatnia inicjatywa w tym względzie. Sejmik województwa kijowskiego, obradujący 27 lutego 1650 r., przyjął do służby województwa na trzy miesiące prywatną „,chorągiew dragońską niemiecką" Jerzego Niemirycza. Stało się to zapewne na prośbę samego rotmistrza, który nie był w stanie wypłacać żołdu swym ludziom, ale i skarb wojewódzki świecił pustkami, bowiem jeszcze pod koniec roku 1651 podkomorzy kijowski nie otrzymał pieniędzy przyznanych mu na tę jednostkę. Zaległa kwota, wynosząca 3000 zł z tytułu żołdu, 1500 zł „pieniędzy karmowych” i 500 zł kuchennego, świadczy, iż dragonom zamierzano płacić tak samo jak kozakom ${ }^{73}$.

Wobec niechętnego stanowiska dworu królewskiego i niemożności zebrania odpowiednich środków finansowych, województwu kijowskiemu nie udało się w 1650 r. utworzyć pułku liczącego pięć chorągwi. Do 30 czerwca tego roku zdołało ono utrzymać w służbie dwie stare chorągwie kozackie oraz jedną nową, dragońską, i były one ostatnimi formacjami wojska powiatowego, które zaciągnął samorząd szlachecki województw ukrainnych na potrzeby obrony domowej. Nie ma bowiem żadnych wzmianek potwierdzających realizację uchwały sejmiku czernihowskiego, dotyczącej zaciągów. Tamtejsza szlachta przez cały czas nie była w stanie powrócić na teren swego województwa, nie było też możliwości zebrania podatków. Zdając sobie z tego sprawę, Czernihowianie zaczęli zabiegać o rozlokowanie w przyszłości oddziałów koronnych w królewszczyznach swej ziemi ${ }^{74}$. Na sejmikach obradujących w Żytomierzu we wrześniu 1650 r. zarówno Kijowianie, jak i Czernihowianie stwierdzili, że w przypadku kolejnych rozruchów są w stanie jedynie osobiście stanąć pod komendą wojewody Adama Kisiela ${ }^{75}$. Pod koniec

${ }^{72} \mathrm{~W}$ odpowiedzi udzielonej 5 maja $1650 \mathrm{r}$. wojsku zaporoskiemu monarcha zapewniał, że przestrzega, by żaden z obywateli województwa kijowskiego do swych dawnych dóbr „z wojskiem jeździć nie ważył się”, ibidem, s. 341.

${ }^{73}$ AJZR, cz. 2, t. 1, Instrukcja poselska sejmiku województwa kijowskiego, Żytomierz, 15 XII 1651, s. 422.

${ }^{74}$ AJZR, cz. 2, t. 1, Instrukcja poselska sejmiku województwa czernihowskiego, Żytomierz, 15 XII 1651, s. 428-429.

${ }^{75}$ CDIAUK, f. 11, op. 1, nr 13, Laudum sejmiku województwa kijowskiego, Żytomierz, 12 IX 1650, k. 499; ibidem, Laudum sejmiku województwa czernihowskiego, Żytomierz, 12 IX 1650, k. 500. 
tego roku wielu z nich zaczęło jednak ponownie emigrować na zachód Polski, obawiając się kolejnego krwawego buntu poddanych, a z początkiem 1651 r. obie strony wznowiły działania wojenne.

Szlachcie ukraińskiej nigdy nie udało się zrealizować ambitnych uchwał z 1649 r., mogących doprowadzić do utrzymywania przez dwa lata kilku tysięcy żołnierzy (5500 przez same tylko województwa kijowskie i czernihowskie). Nie zrealizowano też w pełni skromniejszych planów z następnego roku, przewidujących utworzenie wspólnego dla dwóch wspomnianych województw pułku, liczącego 800 zbrojnych. Chorągwie powiatowe, które wówczas zaciągnęli Kijowianie, nie mogły spełnić pokładanych $\mathrm{w}$ nich nadziei, bowiem $\mathrm{z}$ jednej strony były zbyt słabe liczebnie, $z$ drugiej nie działały na terenie opanowanym przez wojsko koronne. Założenia, że rolę tego ostatniego spełnią Kozacy, wypełniający zapisy ugody zborowskiej, bardzo szybko okazały się mrzonką. Pułkownicy kozaccy nie zamierzali dopuścić do zbierania podatków na kijowskie i czernihowskie wojska obrony domowej, kładąc tym samym dość szybko kres istnieniu nielicznych oddziałów tego typu. $Z$ tego też powodu długi wobec zaciężnych chorągwi obrony domowej $z$ lat 1649-1650 jeszcze przez wiele miesięcy obciążały skarb województwa kijowskiego ${ }^{76}$. W kolejnych latach szlachta niszczonych wojną i opanowanych przez wroga województw ukrainnych nie podejmowała już uchwał dotyczących organizacji wojsk tego typu. Z wojskowych powinności na rzecz państwa została natomiast zwolniona. Niemniej jednak przedstawione tu koncepcje „obrony domowej” ukazują nadzieje tamtejszej noblilitas, iż ustępstwa polityczne na rzecz Kozaczyzny zaporoskiej w połączeniu $\mathrm{z}$ wysiłkiem finansowym, który sama poniesie, pozwolą jej na powrót do domów i przynajmniej częściowe przywrócenie dawnych porządków.

\section{Streszczenie}

Przedmiotem analizy są próby organizacji wojsk samoobrony terytorialnej przez sejmiki województw kijowskiego, bracławskiego i czernihowskiego, podejmowane w latach 1649-1650. Szlachta województw ukrainnych, ogarniętych powstaniem kozackim, schroniła się wówczas na terenie Wołynia, Rusi i Lubelszczyzny. Miała jednak nadzieję, że po zawieszeniu broni z Bohdanem Chmielnickim zdoła powrócić na Ukrainę, a dzięki własnym, samorządowym siłom zbrojnym przywróci na niej lad i pokój.

${ }^{76}$ AJZR, cz. 2, t. 1, Instrukcja poselska sejmiku województwa kijowskiego, Żytomierz, 15 XII 1651, s. 421-423. 
Po wybuchu powstania Chmielnickiego w 1648 r. niektóre sejmiki zwoływane w Koronie i na Litwie zaciągały oddziały wojska strzegącego bezpieczeństwa w województwach i powiatach. Ponownie sięgnięto do tego typu rozwiązań w początkach 1649 r., gdy po wycofaniu się Kozaków na Ukrainę trzeba było zwalczać bunty na opuszczonych przez nich terenach Wołynia i Rusi Czerwonej. Zbiegła przez powstańcami szlachta województw kijowskiego, bracławskiego i czernihowskiego pozostawała jeszcze na wygnaniu, ale również miała nadzieję, że uda się jej szybko powrócić do swych domów. Zdawała sobie przy tym sprawę, że spacyfikowanie zbuntowanych obszarów będzie wymagało własnych sił zbrojnych, stąd podjęła ambitne uchwały przewidujące utworzenie licznych oddziałów jazdy i piechoty. Ostatecznie jedynie województwu kijowskiemu udało się zaciągnąć kilka chorągwi jazdy, które wzięły udział w kampanii zborowskiej 1649 r. Służyły one od czerwca 1650 r. w Żytomierzu, starając się ochraniać okoliczne majątki szlacheckie, ich właścicieli i zabezpieczać zbierające się w tym mieście sejmiki ziemskie. Nie było możliwości rozbudowy owych formacji, a nawet utrzymania ich na dłużej w służbie, co wynikało z wrogiej postawy Kozaków, przeciwdziałających zbieraniu podatków przez szlacheckich poborców i z zakazu wkraczania wojsk koronnych na teren trzech województw Ukrainy.

\section{Attempts to Organize the Forces of "Domestic Defence" by the Nobility of the Kiev, Bracław, and Czernihów Palatinates (1649-1650)}

The subject of an analysis are attempts to organise territorial self-defence force undertaken by the dietines the Kiev, Bracław, and Czernihów palatinates in 16491650. The nobility of the Ukrainian palatinates, engulfed by the Cossack uprising, took shelter in the territory of Volhynia, Red Ruthenia, and the Lublin region. They hoped, however, that after a ceasefire with Bohdan Khmelnytsky they would return to Ukraine, and thanks to their own self-defence armed forces they would be able to restore order and peace.

After the outbreak of the Khmelnytsky Uprising in 1648, some of the dietines summoned in the Polish Crown and Lithuania enlisted troops to protect security in the palatinates and counties. The same measures were adopted in early 1649, when, after the Cossacks retreated to Ukraine, the troops were needed to put down rebellions in the territories they had left in Volhynia and Red Ruthenia. The nobility who fled from the insurgents in the palatinates of Kiev, Bracław, and Czernihów, stayed in exile, but with the hope to be able to return home soon. At the same time the nobles were aware of the fact that in order to suppress the uprising they would have to create their own armed forces. To this end, they adopted ambitious resolutions declaring the enlistment of numerous cavalry and infantry troops. Finally, however, only the Kiev palatinate managed to recruit successfully several cavalry units (each called a choragiew), which fought in the 1649 Zborów campaign. Next year, to June 1650, they served in Żytomierz, trying to protect neighbouring noble estates and their returning owners, and to guard sessions of 
local dietines. There were no possibility, however, to develop those troops or even to prolong their service in the face of both the hostile attitude of the Cossacks who opposed the collection of taxes by tax collectors sent by the nobility, and a ban on the entry of the Crown army to the territory of the three Ukrainian palatinates.

Translated by Grażyna Waluga

\section{Bibliografia}

Akta sejmikowe ziemi chełmskiej 1572-1668, oprac. Wiesław Bondyra, Henryk Gmiterek, Jerzy Ternes, Archiwum Państwowe, Wydawnictwo UMCS, Lublin 2013.

Borowiak Albert, Wojsko powiatowe przed kampania piławiecka 1648 roku, w: Studia nad staropolska sztuka wojenna, t. 2, red. Zbigniew Hundert, Wydawnictwo Napoleon V, Oświęcim 2013, s. 129-160.

Czołowski Aleksander, Z dziejów chmielniczyzny na Podkarpaciu, w: Księga pamiątkowa ku czci Władysława Abrahama, t. 2, Pierwsza Druk. Związkowa, Lwów 1931, s. $387-400$.

Drozdowski Mariusz, My o nas i o innych. Szlachta Rzeczypospolitej wobec Kozaczyzny zaporoskiej w latach 1648-1659, Instytut Badań nad Dziedzictwem Kulturowym Europy, Białystok 2015.

Dworzaczkowa Jolanta, Sprawy wojska na sejmikach wielkopolskich w latach 1648-1661, w: Pax et bellum, red. Karol Olejnik, Wydawnictwo Naukowe UAM, Poznań 1993, s. 55-64.

Gawęda Marcin, Wysitek zbrojny ziemi przemyskiej i sanockiej w latach 1648-1649, „Rocznik Przemyski" 41, 2005, s. 81-104.

Jakuba Michałowskiego wojskiego lubelskiego, a później kasztelana bieckiego księga pamiętnicza, wyd. Antoni Zygmunt Helcel, Towarzystwo Naukowe Krakowskie, Kraków 1864.

Jerlicz Joachim, Latopisiec albo kroniczka, wyd. Kazimierz Władysław Wójcicki, t. 1, Warszawa 1853.

Kupisz Dariusz, Choragwie powiatowe województw małopolskich jako formacje samoobrony terytorialnej w pierwszej połowie XVII wieku, „Studia i Materiały do Historii Wojskowości" 42, 2006, s. 33-57.

Kupisz Dariusz, Choragwie powiatowe ziemi chetmskiej w XVI-XVII wieku, „Rocznik Chełmski" 10, 2006, s. 51-77.

Kupisz Dariusz, Ochrona pogranicza przez siły zbrojne samorzadu województwa ruskiego $w$ drugiej połowie XVII wieku, w: Urzędy państwowe, organy samorzadowe $i$ kościelne oraz ich kancelarie na polsko-ruskim pograniczu kulturowym i etnicznym $w$ okresie od XV do XIX wieku, red. Henryk Gmiterek, Janusz Łosowski, Avalon, Kraków 2010, s. 141-158.

Kupisz Dariusz, Wojska powiatowe samorząów Małopolski i Rusi Czerwonej w latach 1572-1717, Wydawnictwo UMCS, Lublin 2008.

Kupisz Dariusz, Wojsko powiatowe województwa wołyńskiego w XVII wieku, „Науковий вісник Волинського національного університету імені Лесі Українки” 22, 2009 , s. $182-188$. 
Łoziński Władysław, Prawem i lewem. Obyczaje na Czerwonej Rusi w pierwszej połowie XVII wieku, t. 1, Wydawnictwo Literackie, Kraków 1957.

Nagielski Mirosław, Pospolite ruszenie szlachty $w$ świetle kampanii zborowskiej $i$ beresteckiej przeciw Kozakom (1649-1651), w: Studia Historyczno-Wojskowe, t. 3: Armia i społeczeństwo, red. Tomasz Ciesielski, Inforteditions, Zabrze 2009, s. 94-112.

Ochmann Stefania, Sejm koronacyjny Jana Kazimierza w 1649 r., Wydawnictwo Uniwersytetu Wrocławskiego, Wrocław 1985.

Pamiętniki Samuela i Bogusława Kazimierza Maskiewiczów (wiek XVII), oprac. Alojzy Sajkowski, Ossolineum, Wrocław 1961.

Płowy Damian, Od Konstantynowa do Piławiec. Działania wojenne na ziemiach ukrainnych od czerwca do września 1648 roku, Inforteditions, Zabrze-Tarnowskie Góry 2012.

Relacje wojenne z pierwszych lat walk polsko-kozackich powstania Bohdana Chmielnickiego okresu „Ogniem i mieczem”. (1648-1651), oprac. Mirosław Nagielski, Viking, Warszawa 1999.

Serczyk Władysław Andrzej, Na płonącej Ukrainie. Dzieje Kozaczyzny 1648-1651, Książka i Wiedza, Warszawa 1998.

Sprawy i rzeczy ukraińskie. Materyaty do dziejów kozaczyzny i hajdamaczyzny, wyd. Franciszek Rawita-Gawroński, Lwów 1914.

Stolicki Jarosław, Sejmiki ukrainne w latach 1648-1702. Problemy badawcze, w: Patrimoniuт. Студї з ранньомодерної історії Центрально-Східної Європи, t. 1, Ранньомодерна людина. Простір - влада - nраво XVI-XVIII cm, red. В. Михайловський, Я. Століцький, Laurus, Historia Iagellonica, Краків 2015.

Tomkiewicz Władysław, Jeremi Wiśniowiecki (1612-1651), Nakładem Towarzystwa Naukowego Warszawskiego, Warszawa 1933.

Wimmer Jan, Materiały do zagadnienia organizacji i liczebności armii koronnej $w$ latach 1648-1655, „Studia i Materiały do Historii Wojskowości” 4, 1958, s. 477-510.

Wimmer Jan, Wojsko i skarb Rzeczypospolitej u schyłku XVI $i$ w pierwszej połowie XVII wieku, „Studia i Materiały do Historii Wojskowości” 14, 1968, 1, s. 3-91.

Wimmer Jan, Wojsko polskie $w$ drugiej połowie XVII wieku, Wydawnictwo MON, Warszawa 1965.

Джерела з історії Національно-визвольної війни українського народу 1648-1658 рр., t. 1: (1648-1649 pp.), t. 2: (1650-1651), орrac. Юрій Мицик, Київ 2012-2013.

Документи Богдана Хмельницького 1648-1657, оргас. Іван Крип'якевич, Київ 1961. Документы об освободительной войне украинского народа 1648-1654 г2., орrac.

А.3. Барабой, И.Л. Бутич, Київ 1965.

Томашівський Степан, Народні рухи в Галищъьій Руси 1648 р., Лвів 1898.

Biogram: Dariusz Kupisz - dr hab. profesor nadzwyczajny w Instytucie Historii UMCS w Lublinie; obszar zainteresowań: wojskowość polska od końca XVI do początków XVIII w., samorząd szlachecki i jego siły zbrojne, wojny polsko-moskiewskie; kontakt: dariusz.kupisz@poczta.umcs.lublin.pl. 